\title{
Causes and Effects of Workplace Conflict in Midland Bank Ltd: A Case Study on Dhanmondi Branch
}

\author{
Md. Kamrul Islam ${ }^{1}$, Rezaul Karim²
}

\begin{abstract}
${ }^{1+2}$ Department of Business Administration, Atish Dipankar University of Science \& Technology, Banani, Dhaka-1213, Bangladesh.

Correspondence:Md. Kamrul Islam,Department of Business Administration, Atish Dipankar University of Science \& Technology, Banani, Dhaka-1213, Bangladesh ,E-mail: kamrul.ir87@gmail.com
\end{abstract}

Received: September 11, $2017 \quad$ Accepted: September 14, $2017 \quad$ Online Published: September 16, 2017

URL: http://www.cribfb.com/journal/ijbmf

\begin{abstract}
Conflict is one of the major organizational phenomena. Where there is an employee involvement, conflict is obvious to occur. Workplace conflicts happen everywhere and ignoring them can be costly. The objectives of this research are to identify the causes and effects of workplace conflicts and also forecast the ways for the prevention of the occurrence of conflicts in future. A survey was carried out in this regard among the employees of Midland Bank Ltd., Dhanmondi Branch. According to the survey we found that it is the employees' behavior that causes conflicts in organization. Majority of the participants in the survey agreed that the main causes of workplace conflict are the negative criticism \& gossip, denying personal mistakes, jealousy, and moral corruption and using abusive language. The effects that workplace conflicts have in this organization are broken relationship (top most reason), instability and insecurity, loss of commitment to work, voluntary resignation etc. It is recommended that bank should introduce a formal system of information dissemination, manager should learn to practice delegation of authority and there should be adequate interaction and dialogue in conflict resolution.
\end{abstract}

Keywords: Conflict, Workplace, Causes of Conflict, Effects of Conflict.

\section{Introduction}

Conflict is inevitable among humans. When two or more people come in contact with one another in attaining objectives their relationship may become incompatible, inconsistent or incongruent. Actually conflict is the perception of differences in interests among people. Conflict at workplace can be seen between individuals involving colleagues, peers, superiors and subordinates. It can also be between groups involving teams or large group of employees and management. Generally conflicts are seen in four level namely intrapersonal conflicts, interpersonal conflicts, intra-group conflicts and intergroup conflict. Midland Bank is one of the fourth generation scheduled private commercial bank of Bangladesh. It was incorporated on March 20, 2013 under the companies Act 1994. Although it is new but it is a fast growing modern baking organization. The Bank started 
its banking operation on June 20, 2013. Employee conflict in banking organization is an important issue for branch manager, top level manager, owners, regulatory authorities, and other concerned persons interested in understanding the nature of organizational behavior and organizational process. As the banking organization deals with financial transaction; so conflict must be dealt there in first hand. Nonchalance attitude, any linger, prolonged decisions, poor guidance in conflict resolution can bring disaster for the organization.

\section{Literature Review}

According to Stoner and Freeman, (1992), "a conflict is defined as a disagreement between two or more parties with perceived incompatible goals or interests. This disagreement can be about the allocation of resources or clashes regarding goals, values, and so on that can occur on the interpersonal or organizational level." Many authors define conflict in various ways; the common point in the definitions offered though is the parties' perceived incompatible goals or interests. Similarly, at workplace there are numerous interests are represented by the parties converging at that location for a common cause-work. Management of such interests therefore, requires dynamic, proactive and creative conflict management systems put in place to ensure a vibrant favorable work environment. According to David Laton (2008), conflict arises from disagreements over the goals to attain or the methods used to accomplish these goals.

\subsection{Complaints}

According to Collins S.D (2009), "A complaint is an expression of divergence in opinion or the viewpoint between two parties reflecting one party's dissatisfaction." A complaint is a lower level of conflict. Its resolution requires minimal and mutual commitment and engagement from the two parties.

\subsection{Disputes}

According to Collins S.D (2009), disputes have their origins in disagreements between the individuals. The disagreement becomes a dispute when one or the other party cannot accommodate the consequences of the disagreement, and insists on having it resolved because the party feels interests are undermined when the disagreement remains unresolved. When the dispute is not resolved in due time, it degenerates into a conflict

\subsection{Workplace}

The workplace is defined by Masters, M.E and Albright R.R (2002), as "the setting in which work is performed". It can be interpreted as a physical location at which people interact in the process of producing goods or services for an organizational purpose.

\subsection{Conflict at Workplace}

At workplace conflict tends to manifest in two broad categories:

- It can be a conflict between individuals involving colleagues, employees and their managers. In this way, it may be that two workers simply don't get on; or that an individual has a grievance against their supervisor or manager.

- It can be also between groups involving teams or large groups of employees and management. Conflict may take the form of rivalry between teams; or it may be apparent by the lack of trust and cooperation between large groups of employees and management.

On the broad side, Pondy cited by Afzalur (2011) has argued that organizational conflict can best be understood as a dynamic process underlying organizational behavior.According to Roloff (1987, p-496), cited by Warren.O. Lokke (2013, p-6), organizational conflict occurs when members of one group engage in activities presumed 
incompatible with the interests of colleagues within their network, members of other groups, or unaffiliated individuals who utilize the services or products of the organization. Some of the manifestations of conflict behavior are expressing disagreement with the opponent, yelling, verbal abuse, indifference and interference.

2.5 Types of Conflict

Conflict may be classified on the basis of its sources or on the basis of organizational level.

\subsubsection{Affective Conflict}

According to Afzalur, R.M (2011), affective conflict occurs when two interacting social entities while trying to solve a problem together, become aware that their feelings and emotions regarding some or all issues to the conflict are incompatible. This category of conflict is labeled psychological conflict, relationship conflict, emotional conflict or interpersonal conflict.

\subsubsection{Substantive Conflict}

Afzalur R.M (2011), precise that substantive conflict occurs when two or more organizational members disagree on their task or content issues. Jehn (1997) cited by Afzalur characterized this type of conflict as disagreements among group members' ideas and opinions about the task being performed, such as disagreement regarding an organization's current strategic position or determining the correct data to include in a report.

\subsubsection{Conflict of Interest}

According to Afzalur R.M (2011), this type of conflict occurs when each party sharing the same understanding of the situation, prefers a different and somewhat incompatible solution to a problem involving either a distribution of scarce resources between them or a decision to share the task of solving it. Common practice in the Public Service Sector points to where senior staff directs juniors but remain behind to observe how the young staff struggle with performance to meet targets and produce results. When such targets become untenable, the senior staff returns to the juniors for the blame.

\subsubsection{Conflict of Values}

According to Afzalur R.M (2011), this conflict occurs when two social entities differ in their values or ideologies on certain issues or aspects. This is also called ideological conflict. This conflict may affect employees work relationships when their ideological beliefs collide with institutional work requirements.

\subsubsection{Goals Conflict}

According to Afzalur R.M (2011), this conflict occurs when a preferred outcome or an end-state of two social entities becomes incompatible. When one party perceives its interests to fall victim of denigration by the other party, victimization perception arises and then conflict occurs.

\subsubsection{Classification of Conflict Based on Level}

Afzalur M.R (2011), has classified organizational conflict based on the level of analysis. Conflict may be classified as intra-organizational (i.e within organization) or inter-organizational (conflict between two or more organizations). Intra-organizational conflict may also be classified on the basis of level: individual, groups, etc. On this basis, intra-organizational conflict may be classified as intrapersonal, interpersonal, and intra-group and inter-groups. Severally, intra-party conflict may affect the organization where the grieved employee pursues restoration of the harmed interests against the will of the organization to which the employee serves. 


\subsubsection{Intrapersonal Conflict}

According to Afzalur, M.R (2011), intrapersonal conflict is also known as intra-individual or intra-psychic conflict. This is a conflict that happens inside the person's conscience. It occurs when an organizational member is required to perform certain tasks and roles that do not match the employee's expertise, interests, goals, and values and prompts the concerned party to rebel against the given orders.

\subsubsection{Interpersonal Conflict}

Afzalur, M.R (2011) states that interpersonal conflict is also known as dyadic conflict.It refers to the conflict between two or more organizational members of the same or different hierarchical levels or units. The conflict between the two entities happen when one party trespasses the interests of the other and efforts to settling such a dispute remain uncooperative.

\subsubsection{Intergroup Conflict}

Afzalur, M.R (2011) also identifies intergroup conflict as interdepartmental conflict. It refers to conflict between two or more units or groups within an organization. Conflict between headquarter and field staff, labor and leaders or management are examples.

\subsubsection{Intra-group Conflict}

Intra-group conflict refers to the incompatibility, incongruence, or disagreement among the members of a group or its subgroups regarding goals, functions or activities of the group. Jarboe and Witteman define, "An intra-group problem exists whenever a group member perceives a difference what is presently occurring between him or her and the group and he or she desire to occur." (Rahim, 2011)

Dysfunctional Outcomes / Effects of Conflict:

According to Rahim (2011), effects of conflict can be categorized into following parts:

- Conflicts may cause job stress, burnout and dissatisfaction.

- Communication between individual and groups may be reduced.

- A climate of distrust and suspicion may be developed.

- Relationship may be damaged.

- Job performance may be reduced.

- Resistance to change can increase.

- Organizational commitment and loyalty may be affected.

\section{Objectives of the Research}

The study objectives focus on compiling a report on the causes and effects of workplace conflict at Midland Bank Ltd. Among the specific objectives the study intends:

- To identify the causes of conflicts at workplace.

- To identify the effects of conflicts at workplace.

- To identify how to solve those conflicts and forecast the ways for the prevention of the occurrence in future.

\section{Methodology of the Research}

The paper is exploratory in nature and the study is mainly based on primary data and information. A survey includes a questionnaire was conducted regarding causes of workplace conflicts and its probable effects on the organization. The sample size for the survey was on 10 employees. Random sampling technique has been used 
in this study. For better understanding the causes and impacts of conflicts in banking organization; conflict related books, articles and essays have been reviewed.

5. Analysis of the Survey

Table-1: Causes of Conflict at Workplace

\begin{tabular}{lcccc}
\hline \multicolumn{1}{c}{ Causes } & $\begin{array}{c}\text { Strongly } \\
\text { Agree } \\
(\boldsymbol{\%})\end{array}$ & $\begin{array}{c}\text { Agree } \\
\mathbf{( \% )}\end{array}$ & $\begin{array}{c}\text { Disagree } \\
\mathbf{( \% )}\end{array}$ & $\begin{array}{c}\text { Frequency } \\
\text { (No. of } \\
\text { participation) }\end{array}$ \\
\hline Criticism \& Gossip & 50 & 30 & 20 & 10 \\
\hline Denying Personal Mistakes & 50 & 30 & 20 & 10 \\
\hline Employees Misconduct & 30 & 50 & 20 & 10 \\
\hline Stressful Environment & 30 & 50 & 20 & 10 \\
\hline Envy/Jealous & 40 & 30 & 30 & 10 \\
\hline Moral Corruption & 40 & 30 & 30 & 10 \\
\hline Abusive Language & 30 & 30 & 40 & 10 \\
\hline Professional Malpractices & 20 & 20 & 60 & 10 \\
\hline
\end{tabular}

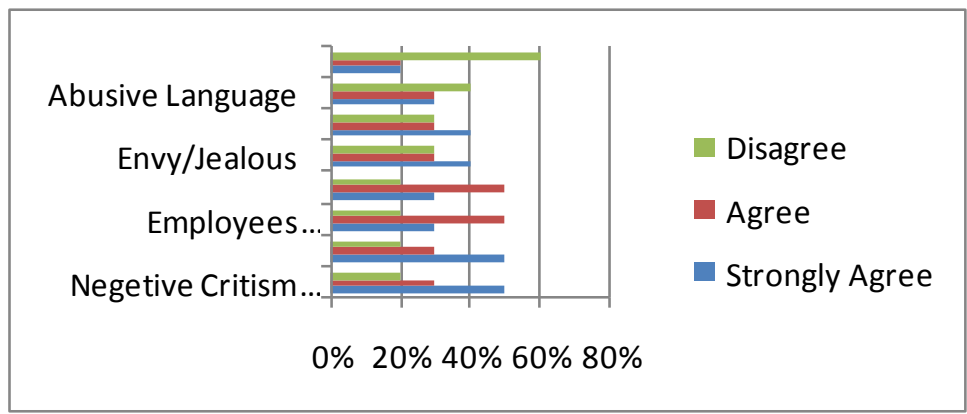

Table-2: Effects of Conflicts at Workplace

\begin{tabular}{lcccc}
\hline \multicolumn{1}{c}{ Effects } & $\begin{array}{c}\text { Strongly } \\
\text { Agree (\%) }\end{array}$ & Agree (\%) & Disagree (\%) & $\begin{array}{c}\text { Frequency } \\
\text { (No. of participation) }\end{array}$ \\
\hline Broken Relationship & 70 & 20 & 10 & 10 \\
\hline Employee Instability & 60 & 30 & 10 & 10 \\
\hline $\begin{array}{l}\text { Loss of Commitment } \\
\text { Work }\end{array}$ & 60 & 30 & 10 & 10 \\
\hline Voluntary Resignation & 30 & 50 & 20 & 10 \\
\hline Forceful Resignation & 40 & 40 & 20 & 10 \\
\hline Moral \& Physical Injuries & 30 & 50 & 20 & 10 \\
\hline Institutional Impact & 30 & 50 & 20 & 10 \\
\hline Decreased Productivity & 50 & 40 & 10 & \\
\hline
\end{tabular}




\section{Findings of the Research}

- According to the survey it is found that it is the employee's behavior that causes conflict in organizations.

- Majority of the participants in the survey agrees that negative criticism \& gossip, denying personal mistakes, envy/jealousy, moral corruption, employee's misconduct, abusive language etc are the main causes of conflict in workplace.

- Most participants disagreed that professional malpractice cannot be a cause of workplace conflict.

- The effects that workplace conflicts have on an organization are broken relationship among employees on top most, followed by employee instability and insecurity, loss of commitment to work, voluntary resignation, resignation, moral \& physical injuries and decreased productivity.

- Few participants even disagreed that workplace conflicts does not have any effect on institutional impact, moral and physical injuries of employees and forceful and voluntary resignation.

- It can also be seen that Midland Bank does not have adequate room for decision making.

- There is no proper system of information dissemination to all employees.

- Less adequate interaction and dialogue in conflict resolution.

- There is no training workshop for employees on conflict resolution procedure.

Recommendation of the Research

Arising from the findings of this study, the following are herewith recommended for Midland Bank Limited

- To avoid rumor mongering, Midland Bank Limited should evolve a proper system of information dissemination to all and sundry.

- Managers should learn to practice delegation of authority to members of staff in the lower cadre.

- Participatory, rather than autocratic style of management should be encouraged.

- There should be adequate interaction and dialogue in conflict resolution.

- Competition for supremacy should not be the priority of the staff of Midland Bank Limited but rather working together in peace and unity to achieve a common goal for the good of the organization should be encouraged.

- Training workshops should be organized for employees of Midland Bank Limited on conflict resolution procedure.

- Ensure regular monitoring to prevent negative criticism and gossiping that might occur in the workplace.

- Provide supportive management system to regularly assist employees who are less efficient so that they won't deny personal mistakes in future preventing any type of conflict.

\section{Conclusion}

It is quite evident that conflicts occur in organizations as a result of competition for supremacy, leadership style, scarcity of common resources etc. This reduces staff satisfaction about the job and also reduces productivity or service rendered. Thus, early recognition of the conflict and paying attention to the conflicting parties is very important. Negotiation between parties involved is the best way to resolve conflict while force should not be used at all. Darling and Fogliasso (1999) conclude that it is impossible to eliminate conflict totally. Mangers who try to eliminate conflict will not last long, while those who manage it well will typically experience both institutional benefits and personal satisfaction. 


\section{References}

Collins, S.D. (2009). Effective Communication. Jessica Kingsley Publishers.

Darling and Fogliaso (1999). Conflict Management across cultural boundaries; a case analysis from a multinational bank. MCB UP Ltd.

David Laton (2008). Causes and impacts of conflicts at workplace. Public Service Commission Rwanda.

Jarboe, S.C. \& Witteman H.R.(1996). Intra-group conflict management in task-oriented groups. Small group research, 27, 316-333.

John, K.A. (1997). A qualitative analysis of conflict types and dimensions in organizational groups. Administrative Science Quarterly, 42,530-557.

Masters, M. E. and Albright R.R. (2002). The complete Guide to conflict resolution in the workplace. AMACOM Publisher.

Pondy, L. (1992). Reflection on organizational conflict. Journal of organizational Behavior, 13, 257-261.

PSC of Rwanda (2014). Causes and impacts of conflicts at workplace: https://www.google.com/search?q=causes+and+impacts+of+conflicts+at+workplace\&ie=utf- $8 \&$ oe=utf- 8 [Extract on 23 Aug.2016].

Rahim, M. A. (1986). Managing Conflict in Organizations. Praeger Publishers, New York.

Rahim, M. A (2000). Managing conflicts in organizations (Westport, CT: Quorum Books).

Rahim, M. A. (2001). Managing Conflict in Organizations. Praeger Publishers, New York.

Roloff, M.E.(1987). Communication and Conflict. In C.R. Berger \& S.H. Chaffee (Eds.).

Handbook of Communication Science (PP.484-534). Newbury Park, CA: Sage.

Stoner and Freeman (1992). Management. Prentice Hall.

Warren. O. Lokker (2013). Patient care complaints management. Vancouver Island Health Authority.

\section{Copyrights}

Copyright for this article is retained by the author(s), with first publication rights granted to the journal. 